\title{
Diversity of the genus Ganoderma in Punjab (India)
}

\section{Gurpreet Kaur $^{1}$, Avneet Pal Singh ${ }^{2 *} \&$ Gurpaul Singh Dhingra ${ }^{2}$}

\author{
${ }^{1}$ Department of Agriculture, Khalsa College, Amritsar 143002, Punjab, India \\ ${ }^{2}$ Department of Botany, Punjabi University, Patiala 147002, Punjab, India
}

Received 10 December 2017 / Accepted 27 December 2017 / Published 31 December 2017

Kaur, G., Singh, A.P. \& Dhingra, G.S. 2017. Diversity of the genus Ganoderma in Punjab (India). Mycobiota 7: 25-49. doi: 10.12664/mycobiota.2017.07.05

\begin{abstract}
Twelve species of the genus Ganoderma, $G$. amboinense, $G$. applanatum, $G$. australe, $G$. crebrostriatum, $G$. curtisii, $G$. lobatum, $G$. lucidum, $G$. mediosinense, $G$. parvulum, $G$. ramosissimum, $G$. resinaceum, and $G$. subumbraculum, are reported and illustrated from different localities of state of Punjab (India) and its capital Chandigarh, which is also a union territory. Of these, $G$. mediosinense is a new record for India, while $G$. amboinense, $G$. australe, $G$. curtisii, $G$. crebrostriatum, $G$. lobatum, $G$. parvulum, $G$. ramosissimum, $G$. resinaceum, and $G$. subumbraculum are reported for the first time from the state of Punjab. A key to all twelve species from the study area is presented.
\end{abstract}

Key words: Agaricomycetes, Basidiomycota, Ganoderma, India, laccate polypores, Punjab, taxonomy

\section{Introduction}

The genus Ganoderma P. Karst. is characterized by having annual to perennial, pileate, sessile to stipitate sporocarps; laccate or non-laccate, azonate to zonate abhymenial surface; poroid hymenial surface; homogeneous/duplex/three layered context; trimitic hyphal system; thin-walled, clamped generative hyphae; thick-walled, non-septate, occasionally branched skeleto-binding hyphae; much branched, randomly oriented, thick-walled, nonseptate binding hyphae; hymeniodermis/anamixodermis/trichodermis type of pilear crust; tetrasterigmate basidia with a basal clamp and ellipsoid, truncate, guttulate, brownish, inamyloid, acyanophilous basidiospores.

Ganoderma was established by Karsten (1881), with a type species G. lucidum. This genus is distributed worldwide with 207 species (Mycobank 2017). Of the 62 species

\footnotetext{
*Corresponding author: e-mail: avneetbot@gmail.com
} 
reported from India so far, two species, G. colossus and G. fulvellum, have been shifted to the genera Tomophagus and Inocybe, respectively, thus leaving 60 species.

Punjab, primarily an agrarian state, was selected as the study area for the present studies. Champion and Seth (1968) categorised the vegetation of the study area into northern dry mixed deciduous forests, dry deciduous scrub forests, dry bamboo brake forests, khairsissoo forests and Shiwalik chir pine forests. Only two species of Ganoderma, G. applanatum and G. lucidum, are known from the study area.

During the fungal forays conducted in the monsoon months of the years 2012-2015 in different localities of the state of Punjab and its capital Chandigarh, numerous specimens of Ganoderma were collected by the authors. These specimens have been identified on the basis of macroscopic and microscopic characters. Of the 12 species reported herein, ten species, G. amboinense, G. australe, G. curtisii, G. crebrostriatum, G. lobatum, G. mediosinense, G. parvulum, G. ramosissimum, $G$. resinaceum, and G. subumbraculum, are new records for the study area. It is pertinent to mention that $G$. mediosinense is reported for the first time from India. A key to all twelve species is presented.

\section{Material and methods}

The present work on the diversity of genus Ganoderma is based on specimens, collected from different localities in the state of Punjab and Union Territory of Chandigarh (India), during the monsoon months of the years 2012-2015.

\section{Fungal forays and collection of the specimens}

The basidiocarps of Ganoderma species were carefully segregated from the substrate with the help of a chisel and hammer. The field observations pertaining to place of collection, type of vegetation, substrate, date of collection, nature of pileus, mode of attachment, abhymenial surface, hymenial surface, margins, etc. of collected specimens were recorded carefully. Each collected specimen was assigned with a temporary collection number. The photographs depicting the details of abhymenial/hymenial surface were taken using Nikon/Cannon DSLR camera.

\section{Drying and preservation}

The collected specimens were spread on blotting/brown paper sheets and were dried either in sun or by using an electric drier/blower. The dried specimens were packed in Zip lock pouches which were placed inside the bond paper envelopes pasted with the herbarium label having essential details. For the preservation of the dried specimen 1,4-paradichlorobenzene crystals were put in each packet. All of the packed specimens were placed in the cardboard boxes. All studied specimens have been deposited at the Herbarium of Department of Botany, Punjabi University, Patiala (PUN).

\section{Microscopic studies}

Micromorphological studies were performed by making crush mounts and transverse section cutting of the basidiocarp in 3, 5, and $10 \%$ potassium hydroxide, $1 \%$ phloxine 
in water, $1 \%$ congo red in water, sulphovanillin $(0.5 \mathrm{~g}$ vanillin $+4 \mathrm{ml}$ conc. sulphuric acid $+2 \mathrm{ml}$ distilled water $)$, Melzer's reagent $(0.5 \mathrm{~g}$ iodine $+1.5 \mathrm{~g}$ potassium iodide $+20 \mathrm{~g}$ chloral hydrate $+20 \mathrm{ml}$ distilled water), and $1 \%$ cotton blue in lactophenol. Amyloidity and cyanophilous reactions of microscopic structures were observed in Melzer's reagent and cotton blue respectively. The microscopic attributes pertaining to hyphae (width, thickness, branching, etc.), cuticular elements (type, shape, size, thickness, etc.), basidia (shape, size, sterigmata, etc.), basidiospores (shape, size, reaction, etc.) were observed under a compound microscope. The outline of all the microscopic structures was drawn using a camera lucida.

\section{Data compilation and identification}

The macro- and micromorphological details were compiled in the form of a description which was compared with the published literature (Murill 1902; Bagchee et al. 1954; Bakshi 1971; Steyaert 1972; Corner 1983; Ding 1989; Ryvarden \& Gilbertson 1993; Núňez \& Ryvarden 1997; Sharma 2000, 2012; Ryverden \& Melo 2014) for identification.

\section{Taxonomy}

\section{Key to the species of Ganoderma}

1 Sporocarps with laccate abhymenial surface $\ldots \ldots \ldots \ldots \ldots \ldots \ldots \ldots$

$1^{*}$ Sporocarps with non-laccate abhymenial surface $\ldots \ldots \ldots \ldots \ldots \ldots \ldots$

2 Pilear crust trichodermis .................... applanatum

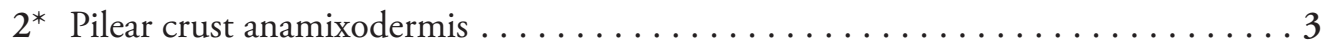

3 Sporocarps spathulate to dimidiate .................. australe

$3^{*}$ Sporocarps applanate . . . . . . . . . . . . . . . . . G. lobatum

4 Sporocarps sessile ...................... G. parvulum

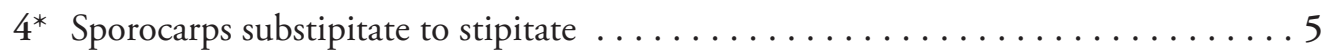

5 Sporocarps substipitate, pileus semicircular to dimidiate . . . . . . . G. resinaceum

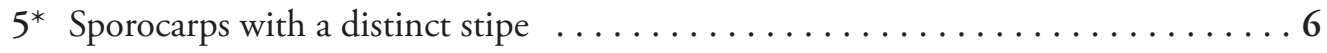

6 Stipe dichotomously to trichotomously to irregularly branched .. G. ramosissimum

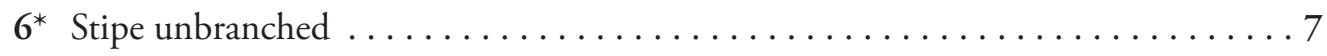

7 Context three layered ...................... subumbraculum

$7^{*}$ Context not as above $\ldots \ldots \ldots \ldots \ldots \ldots \ldots \ldots \ldots \ldots \ldots$

8 Stipe lateral to dorsolateral $\ldots \ldots \ldots \ldots \ldots \ldots \ldots \ldots \ldots \ldots$

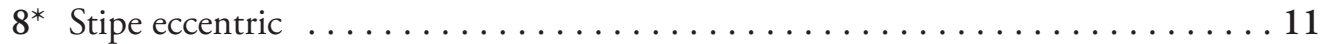

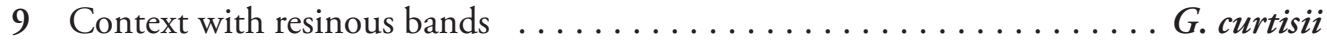




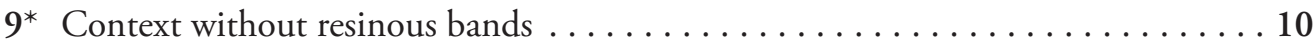

10 Sporocarps dimidiate to reniform $\ldots \ldots \ldots \ldots \ldots \ldots \ldots \ldots$ G. amboinense

10* Sporocarps semicircular ....................... crebrostriatum

11 Sporocarps rosette-like with homogeneous context ......... G. mediosinense

11* Sporocarps dimidiate with homogeneous to duplex context ......... G. lucidum

1. Ganoderma amboinense (Lam.) Pat., Bulletin de la Société Mycologique de France 3: 171, 1887. - Agaricus amboinensis Lam., Encyclopédie Méthodique, Botanique 1(1): 49, 1783.

Fig. 1

Sporocarp annual, stipitate; pileus up to $14 \times 8.5 \times 1.5 \mathrm{~cm}$, dimidiate to reniform, corky when fresh, woody on drying; abhymenial surface concentrically zonate and sulcate, radially rugose, laccate, reddish brown to violet-brown when fresh, not changing much on drying; hymenial surface poroid, reddish grey when fresh, not changing much on drying; pores 6-8 per $\mathrm{mm}$, round to angular; dissepiments thick, entire; pore tubes up to $6 \mathrm{~mm}$ long, dull red; context up to $9 \mathrm{~mm}$ thick, soft, greyish red, homogeneous; margins obtuse, irregularly wavy to deeply lobed, greyish orange to brownish orange on the abhymenial side, paler concolourous on the hymenial side, sterile up to $4 \mathrm{~mm}$. Stipe up to $8 \times 3.5 \mathrm{~cm}$, lateral, subcylindrical to flexuous, solid, violet brown, laccate. Pilear crust as hymeniodermis. Cuticular elements 43-60 × 7.5-9.7 $\mu \mathrm{m}$, clavate, thick-walled, with or without septa, brown, inamyloid. Hyphal system trimitic. Generative hyphae up to $3.7 \mu \mathrm{m}$ wide, branched, septate, clamped, thin-walled. Skeleto-binding hyphae up to 5.3 $\mu \mathrm{m}$ wide, non-septate, thick-walled. Binding hyphae up to $3.1 \mu \mathrm{m}$ wide, with arboriform branching, non-septate, thick-walled. Basidia not seen. Basidiospores 8.7-11.5 × 5.6-7.4 $\mu \mathrm{m}$, ellipsoid, truncate at the distal end; guttulate, inamyloid, acyanophilous; perispore thin, subhyaline, under LM smooth, exospore thick, brown, with prominent pillars.

Specimen examined: INDIA, Punjab: Sangrur, Chittanwala, in association with roots of Dalbergia sissoo, $30.368^{\circ} \mathrm{N}, 75.867^{\circ} \mathrm{E}$, alt. $252 \mathrm{~m}, 6$ Sept 2015, Gurpreet and Avneet 8511 (PUN).

Comments. This species is characteristic in having hymeniodermis pilear crust, laccate abhymenial surface and stipe. Earlier from India, it has been reported/listed from Tamil Nadu and Maharashtra (Sharma 2012; Ranadive 2013). It is reported herein for the first time from Punjab.

2. Ganoderma applanatum (Pers.) Pat. Bulletin de la Société Mycologique de France 5: 67, 1889. - Boletus applanatus Pers. Observationes Mycologicae 2: 2, 1799.

Fig. 2

Sporocarp perennial, sessile, pileus up to $12 \times 6 \times 2.6 \mathrm{~cm}$, applanate, solitary to imbricate, woody; abhymenial surface non-laccate, rough to irregularly zonate and sulcate, greyish red to brownish orange to light brown to brown when fresh, dull red to reddish brown on drying; hymenial surface poroid, reddish grey when fresh, orange white to pale orange on drying; pores round, 4-5 per mm; dissepiments thick, entire; context up to 1.5 

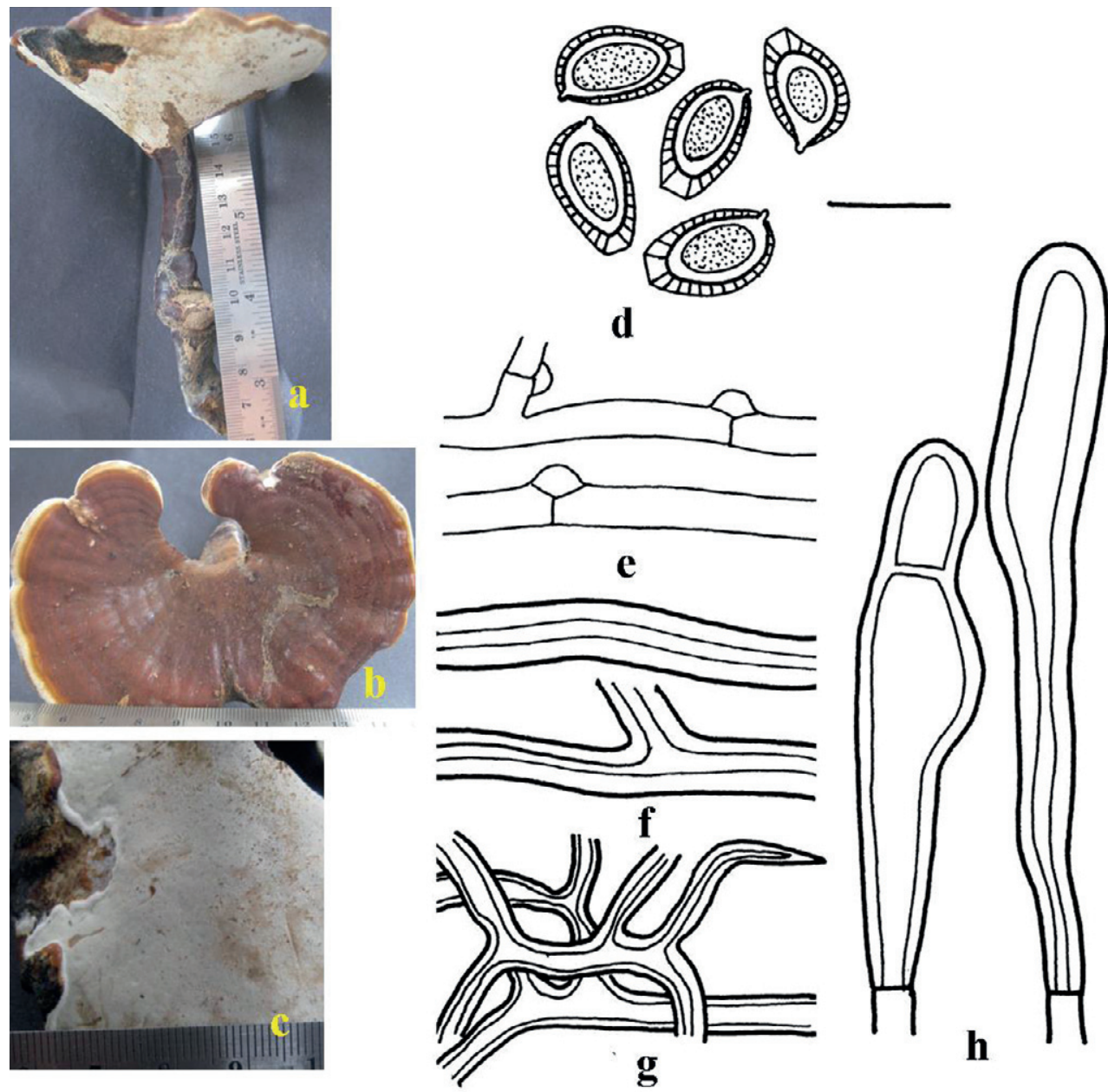

Fig. 1. Ganoderma amboinense: a. Sporocarp with stipe. b, c. Sporocarp showing abhymenial and hymenial surface. d. Basidiospores. e. Generative hyphae. f. Skeleto-binding hyphae. g. Binding hyphae. h. Cuticular elements. Scale bar $(\mathrm{d}-\mathrm{h})=10 \mu \mathrm{m}$

cm thick, reddish brown; pore tubes up to $1.1 \mathrm{~cm}$ long, dull red; margins obtuse, wavy, yellowish grey to orange white on both abhymenial and hymenial sides, sterile up to 3 $\mathrm{mm}$. Pilear crust as trichodermis, fragile, composed of agglutinated thin-walled generative hyphae, thick-walled, brown, skeletal hyphae and binding hyphae. Hyphal system trimitic. Generative hyphae up to $4 \mu \mathrm{m}$ wide, branched, septate, clamped, thin-walled, subhyaline. Skeleto-binding hyphae up to $3.4 \mu \mathrm{m}$ wide, with arboriform branching, non-septate, thickwalled. Skeletal hyphae up to $3.8 \mu \mathrm{m}$ wide, non-septate, thick-walled. Basidia not seen. Basidiospores 7.6-10.3 × 4.5-6.8 $\mu \mathrm{m}$, ovoid, smooth, truncate at the distal end; guttulate, inamyloid, acyanophilous; perispore thin, subhyaline, smooth; exospore thick, brown, bearing an inter-wall pillars. 
Specimen examined: INDIA, Union Territory of Chandigarh: Sector $18 \mathrm{D}$ park, at the base of trunk of Cassia fistula, $30.741^{\circ} \mathrm{N}, 76.768^{\circ} \mathrm{E}$, alt. $341 \mathrm{~m}, 18$ Aug 2014, Dhingra 8517 (PUN).

Comments. This species differs from the previous one in having applanate sporocarps with trichodermis type pilear crust. From India, it has earlier been reported/listed from West Bengal and Assam (Bose 1920, 1922, 1937), Uttarakhand (Bagchee et al. 1954), West Bengal (Banerjee 1947; Sharma \& Ghosh 1989), Uttarakhand (Thind \& Chatrath 1960; Steyaert 1972), Madhya Pradesh (Saxena 1961), plains and temperate Himalaya (Bakshi 1971), Uttarakhand, Himachal Pradesh and Maharashtra (Steyaert 1972), Himachal Pradesh, Jammu and Kashmir and Uttarakhand (Dhanda 1977), Arunachal Pradesh (Singh 1987), district Hoshiarpur in Punjab (Lalji 2003), Himachal Pradesh and Uttarakhand (Sharma 1985, 2000, 2012), Maharashtra (Bhosle et al. 2010; Ranadive et. al. 2011; Ranadive 2013), and Uttarakhand (Singh 2016).

3. Ganoderma australe (Fr.) Pat., Bulletin de la Société Mycologique de France 5: 71, 1889. - Polyporus australis Fr., Elenchus Fungorum 1: 108, 1828.

Fig. 3

Sporocarp perennial, sessile, pilei up to $9 \times 14 \times 3 \mathrm{~cm}$, solitary, arising in association with old sporocarp, spathulate to dimidiate, corky when fresh, woody on drying; abhymenial surface non-laccate, rugose, concentrically sulcate and zonate towards the peripheral region, greyish brown to brown when fresh, reddish brown on drying; hymenial surface poroid, reddish grey to greyish brown when fresh, greyish brown on drying; pores angular, 3-5 per $\mathrm{mm}$; dissepiments thick, entire; context up to $1.5 \mathrm{~cm}$ thick, reddish brown, homogeneous; pore tubes up to $1.5 \mathrm{~cm}$ long, reddish brown; margins obtuse, sterile up to $3 \mathrm{~mm}$, concolorous on the hymenial side, reddish grey on the abhymenial side. Pilear crust as anamixodermis, hard, dark reddish brown, composed of agglutinated subhyaline, thin-walled generative hyphae, thick-walled, non-septate, occasionally branched, brown skeletal hyphae and much branched, randomly oriented, thick-walled, non-septate, lightbrown binding hyphae. Hyphal system trimitic. Generative hyphae up to $2.2 \mu \mathrm{m}$ wide, branched, septate, clamped, thin-walled, subhyaline. Skeletal hyphae up to $7.1 \mu \mathrm{m}$ wide, occasionally branched, non-septate, thick-walled, brown. Binding hyphae up to $3.1 \mu \mathrm{m}$ wide, arboriform, much branched, non-septate, thick-walled, light brown. Basidia not seen. Basidiospores 8-11.4 × 5.2-7.1 $\mu \mathrm{m}$, ellipsoid, truncate at the distal end; guttulate, inamyloid, acyanophilous; perispore thin, subhyaline, smooth; exospore thick, brown, bearing an inter-wall pillars.

Specimen examined: INDIA, Union Territory of Chandigarh: Udyog Path, opposite Gate no. 3 of Panjab University, on trunk of Acacia nilotica, $30.760^{\circ} \mathrm{N}, 76.765^{\circ} \mathrm{E}$, alt. 334 m, 6 Oct 2013, Gurpreet and Avneet 8512 (PUN).

Comments. This species can be differentiated from G. amboinense in having anamixodermis pilear crust. It is reported herein for the first time from the study area. From India, it has earlier been reported/listed from Maharashtra, West Bengal, Kerala and Himachal Pradesh (Bakshi 1971; Sharma \& Ghosh 1989; Leelavathy \& Ganesh 2000; Sharma 2000, 2012; Kaur 2013; Ranadive 2013). 

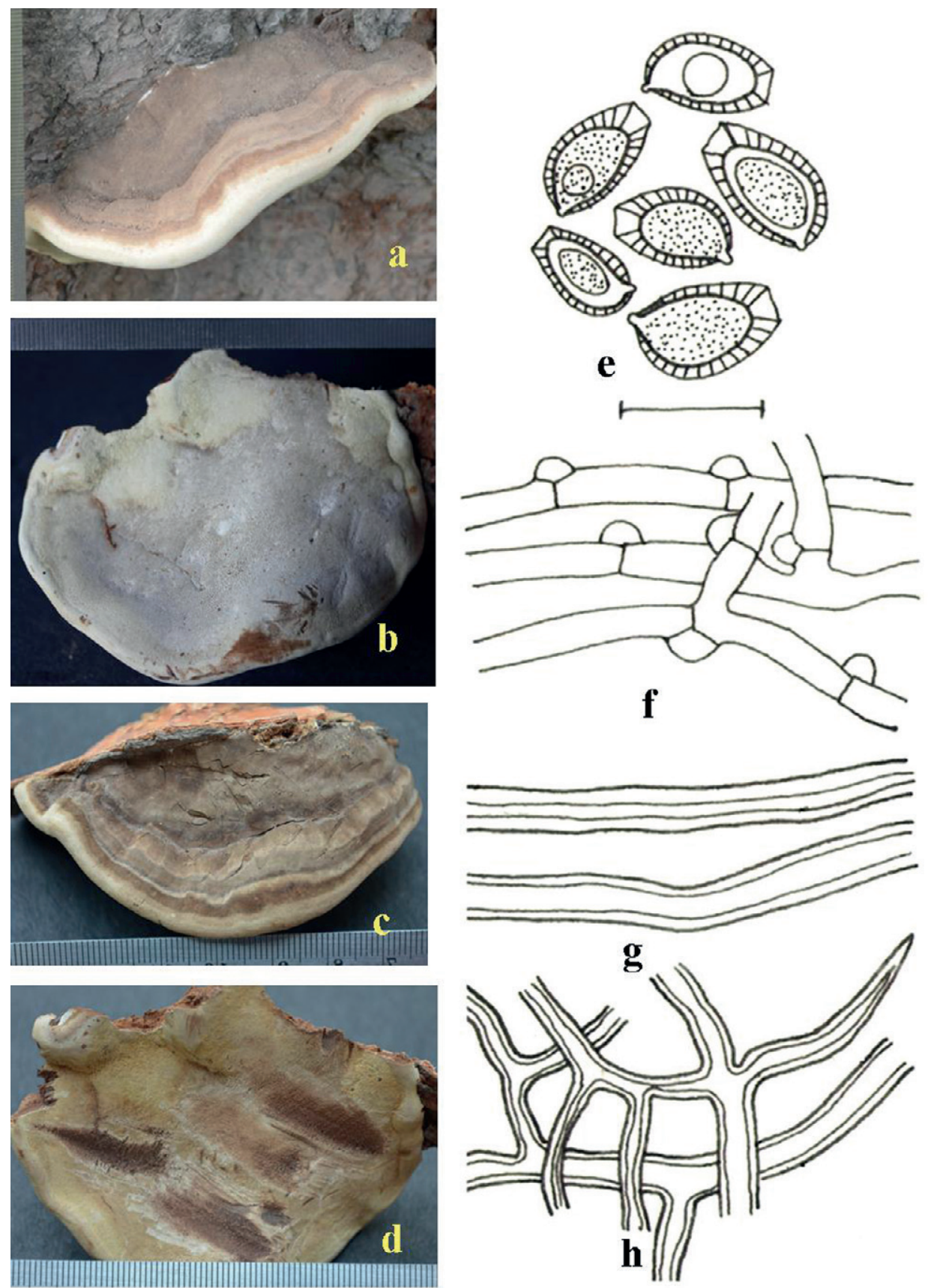

Fig. 2. Ganoderma applanatum: a. Sporocarp in association with host showing abhymenial surface (fresh). b. Sporocarp showing hymenial surface (fresh). c, d. Sporocarp showing abhymenial and hymenial surface (dry). e. Basidiospores. f. Generative hyphae. g. Skeletobinding hyphae. h. Binding hyphae. Scale bar $(\mathrm{e}-\mathrm{h})=10 \mu \mathrm{m}$ 

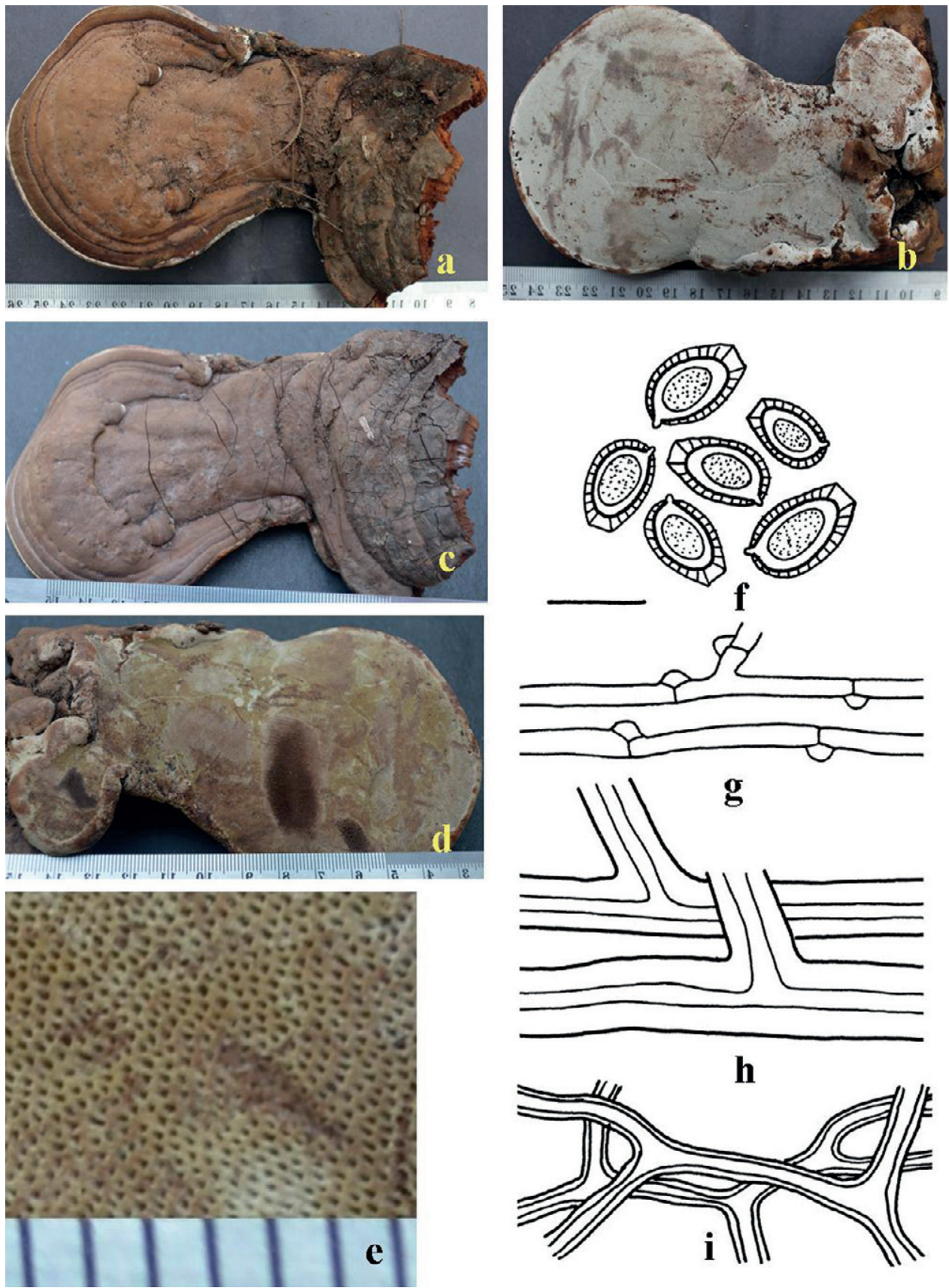

Fig. 3. Ganoderma australe: a, b. Sporocarp showing abhymenial and hymenial surface (fresh). c, d. Sporocarp showing abhymenial and hymenial surface (dry). e. Pores. f. Basidiospores. g. Generative hyphae. h. Skeleto-binding hyphae. i. Binding hyphae. Scale bar (fi) $=10 \mu \mathrm{m}$ 
4. Ganoderma crebrostriatum J.D. Zhao \& L.W. Hsu, Acta Mycologica Sinica 2: 161, 1983.

Fig. 4

Sporocarp annual, semicircular, stipitate; pileus up to $12 \times 13 \times 2 \mathrm{~cm}$, corky; abhymenial surface laccate, sulcate, brownish orange to reddish brown when fresh, light brown to reddish brown on drying; hymenial surface poroid, greyish red when fresh, greyish brown to brown on bruising as well as drying; pores 4-5 per $\mathrm{mm}$, round to angular; dissepiments thin, entire; pore tubes up to $6 \mathrm{~mm}$ long, light brown; context up to $1.4 \mathrm{~cm}$ thick, dark brown, homogeneous; margins obtuse, somewhat irregular. Stipe up to $9 \times 3$ $\mathrm{cm}$, dorsolateral, cylindrical with swollen base, solid, brownish orange to reddish brown, laccate. Pilear crust as hymeniodermis, light brown. Cuticular elements 33.5-44.7 × 11$13 \mu \mathrm{m}$, clavate to subclavate or irregular, sinuous, generally lobed, sometimes with short protuberances, amyloid. Hyphal system trimitic. Generative hyphae up to $3.4 \mu \mathrm{m}$ wide, branched, septate, clamped, thin-walled, subhyaline. Skeleto-binding hyphae up to $6 \mu \mathrm{m}$ wide, non-septate, thick-walled, rarely branched. Binding hyphae up to $4.3 \mu \mathrm{m}$ wide, with arboriform branching, non-septate, thick-walled. Basidia not seen. Basidiospores 7-12.1 $\times$ 4.7-7 $\mu \mathrm{m}$, ellipsoid to subellipsoid, truncate at the distal end; guttulate, inamyloid, acyanophilous; perispore thin, subhyaline, smooth; exospore thick, brown, bearing an inter-wall pillars.

Specimen examined: INDIA, Union Territory of Chandigarh: Sector $18 \mathrm{D}$ park, in association with roots of Cassia fistula, $30.741^{\circ} \mathrm{N}, 76.768^{\circ} \mathrm{E}$, alt. $341 \mathrm{~m}, 15$ Aug 2015, Gurpreet and Dhingra 8516 (PUN).

Comments. This species is characterized by laccate abhymenial surface, dark brown context and cuticular elements with short protuberances. It is reported herein for the first time from the study area. From India, it has earlier been reported from Uttarakhand (Singh 2016).

5. Ganoderma curtisii (Berk.) Murrill, North American Flora 9(2): 120, 1908. - Polyporus curtisii Berk., Hooker's Journal of Botany and Kew Garden Miscellany 1: 101, 1849.

Fig. 5

Sporocarps annual, semicircular, stipitate; pileus up to $15 \times 14 \times 2.6 \mathrm{~cm}$, corky; abhymenial surface laccate, sulcate, weakly zonate towards the margin, radially-rugose, garnet brown when fresh, not changing much on drying; hymenial surface poroid, greyish red when fresh, greyish brown to brown on bruising as well as drying; pores 5-6 per mm, round to angular; dissepiments thin, entire; pore tubes up to $1.2 \mathrm{~cm}$ long, greyish brown; context up to $1.4 \mathrm{~cm}$ thick, fibrous, soft, with resinous bands, duplex, reddish brown zone near the pore tubes, light brown towards the abhymenial side; margins thinning, irregular, acute to somewhat obtuse, sterile up to $1 \mathrm{~mm}$, concolorous on the hymenial as well as abhymenial sides. Stipe up to $7 \times 2.7 \mathrm{~cm}$, dorsolateral, subcylindrical, somewhat flattened, violet brown, laccate. Pilear crust as hymeniodermis. Cuticular elements 41$111 \times 6.8-9 \mu \mathrm{m}$, clavate to subclavate, sinuous, sometimes lobed, smooth, thick-walled, amyloid in the apical part. Hyphal system trimitic. Generative hyphae up to $3.3 \mu \mathrm{m}$ wide, branched, septate, clamped, thin-walled, subhyaline. Skeletal hyphae up to $7.6 \mu \mathrm{m}$ wide, occasionally branched, non-septate, thick-walled, brown. Binding hyphae up to 

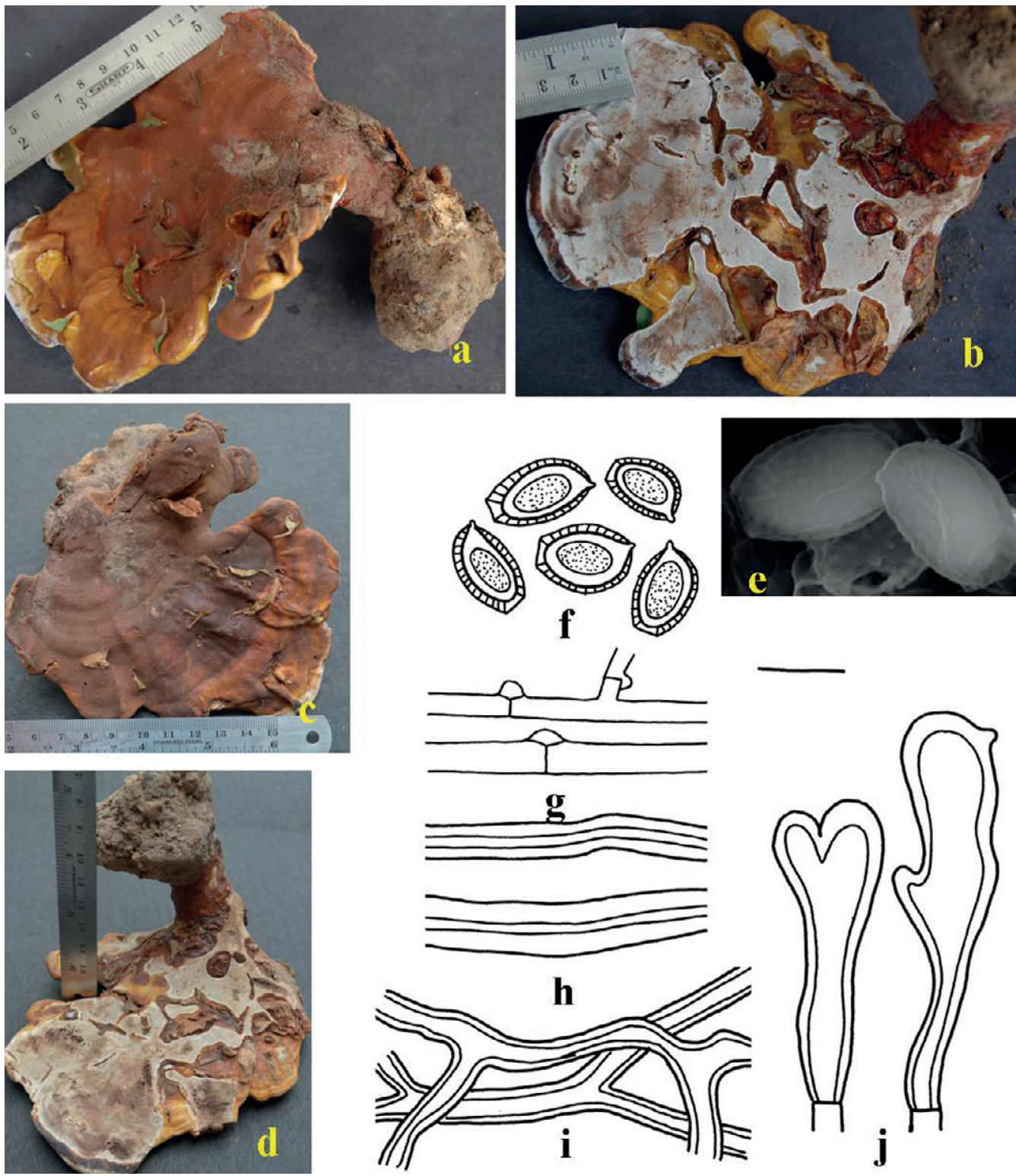

Fig. 4. Ganoderma crebrostriatum: a, b. Sporocarp showing abhymenial and hymenial surface (fresh). c, d. Sporocarp showing abhymenial and hymenial surface (dry). e. Basidiospores in SEM. f. Basidiospores. g. Generative hyphae. h. Skeleto-binding hyphae. i. Binding hyphae. j. Cuticular elements. Scale bar $(\mathrm{f}-\mathrm{j})=10 \mu \mathrm{m}$ 

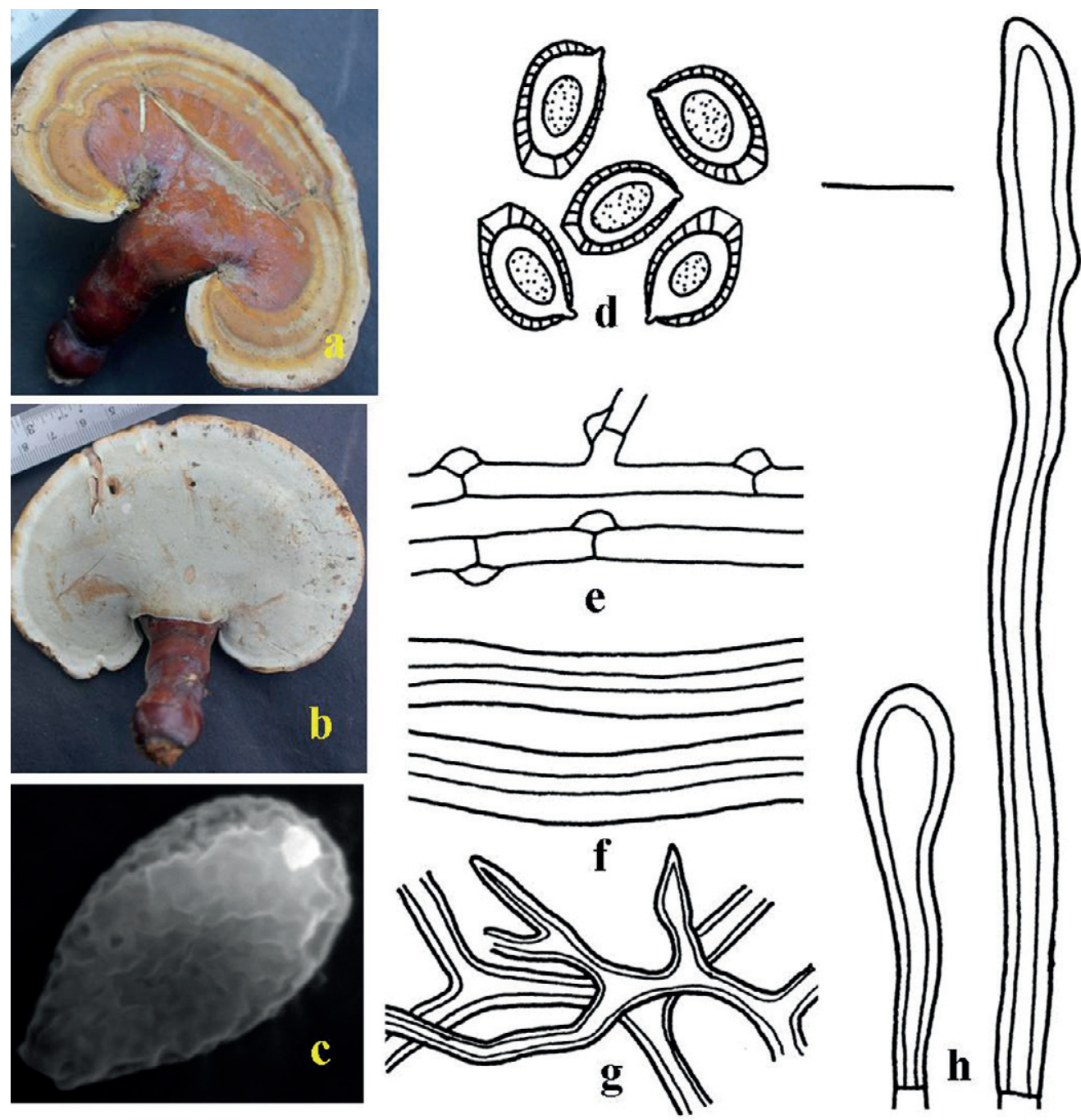

Fig. 5. Ganoderma curtisii: a, b. Sporocarp showing abhymenial and hymenial surface. c. Basidiospore in SEM. d. Basidiospores. e. Generative hyphae. f. Skeleto-binding hyphae. g. Binding hyphae. h. Cuticular elements. Scale bar $(\mathrm{d}-\mathrm{h})=10 \mu \mathrm{m}$

$3.8 \mu \mathrm{m}$ wide, much branched, non-septate, thick-walled, yellowish brown. Basidia not seen. Basidiospores 12-14.5 × 8.3-9.9 $\mu \mathrm{m}$, ellipsoid, truncate at the distal end; guttulate, inamyloid, acyanophilous; perispore thin, subhyaline, smooth; exospore thick, brown, bearing an inter-wall pillars.

Specimens examined: INDIA, Punjab, Roopnagar: Boat Club, in association with roots of dried angiospermous tree, $30.965^{\circ} \mathrm{N}, 76.523^{\circ} \mathrm{E}$, alt. $262 \mathrm{~m}, 5$ Sept 2012, Gurpreet and Avneet 8515 (PUN); Boat Club, in association with roots of Acacia nilotica, $30.965^{\circ}$ N, 76.523 E, alt. 262 m, 5 Sept 2012, Gurpreet and Avneet 8513 (PUN); Boat Club, in 
association with roots of dried angiospermous tree, $30.965^{\circ} \mathrm{N}, 76.523^{\circ} \mathrm{E}$, alt. $262 \mathrm{~m}$, 5 Sept 2012, Gurpreet and Avneet 8514 (PUN).

Comments. This species is characteristic in having stipitate sporocarps and duplex context with resinous bands. It is reported herein for the first time from Punjab. From India, it has earlier been reported/listed from Maharashtra (Foroutan \& Vaidya 2007; Bhosle et al. 2010; Ranadive 2013), Uttarakhand, Meghalaya and West Bengal (Sharma 2000, 2012), Himachal Pradesh (Kaur 2013), and Uttarakhand (Singh 2016).

6. Ganoderma lobatum (Schwein.) G.F. Atk., Annales Mycologici 6: 190, 1908. - Polyporus lobatus Schwein., Transactions of the American Philosophical Society 4(2): 157, 1832.

Fig. 6

Sporocarp perennial, as the new pileus develops from the lower side of old pileus in the subsequent years, sessile, pileus up to $32 \times 17 \times 7.2 \mathrm{~cm}$, applanate, woody; abhymenial surface non-laccate, sulcate, greyish brown to brown, light brown to brown on drying; hymenial surface poroid, greyish red when fresh, greyish brown to brown on bruising as well as drying; pores $4-5$ per $\mathrm{mm}$, round to somewhat angular; dissepiments thick, entire; pore tubes up to $4 \mathrm{~cm}$ long, dark brown; context up to $3.2 \mathrm{~cm}$ thick, reddish brown; margins irregularly wavy to lobed, obtuse, sterile up to $1 \mathrm{~mm}$, paler concolorous on the hymenial side, concolorous on the abhymenial side. Pilear crust as anamixodermis, hard, dark brown, composed of agglutinated subhyaline, thin-walled generative hyphae, thickwalled, non-septate, occasionally branched, brown skeletal hyphae and much branched, randomly oriented, thick-walled, non-septate, light brown binding hyphae. Hyphal system trimitic. Generative hyphae up to $2.7 \mu \mathrm{m}$ wide, branched, septate, clamped, thin-walled, subhyaline. Skeleto-binding hyphae up to $4.6 \mu \mathrm{m}$ wide, non-septate, thick-walled, rarely branched. Binding hyphae up to $4 \mu \mathrm{m}$ wide, with arboriform branching, non-septate, thick-walled. Basidia not seen. Basidiospores 7.9-10 × 5.2-5.9 $\mu \mathrm{m}$, ellipsoid, truncate at the distal end; guttulate, inamyloid, acyanophilous; perispore thin, subhyaline, smooth; exospore thick, brown, the two walls connected by inter-wall pillars.

Specimen examined: INDIA, Union Territory of Chandigarh: Udyog Path, opposite Gate no. 3 of Panjab University, on trunk of Acacia nilotica, $30.760^{\circ} \mathrm{N}, 76.765^{\circ} \mathrm{E}$, alt. 334 m, 6 Oct 2013, Gurpreet and Avneet 8518 (PUN).

Comments. It is a perennial species, reported herein for the first time from the study area. From India, it has earlier been described/listed from Himachal Pradesh (Kaur 2013), Uttarakhand (Singh 2016) and Maharashtra (Foroutan \& Vaidya 2007; Ranadive et al. 2011, 2013).

7. Ganoderma lucidum (Curtis) P. Karst., Revue Mycologique Toulouse 3(9): 17, 1881. Boletus lucidus Curtis, Fl. Londinensis 4: 72, Table 224, 1781.

Fig. 7

Sporocarps annual, stipitate, pileus up to $21.5 \times 17 \times 2 \mathrm{~cm}$, dimidiate, corky; abhymenial surface laccate, sulcate, zonate, reddish brown to brown when fresh as well as on drying; hymenial surface poroid, reddish grey when fresh, greyish brown on bruising, orange grey on drying; pores $4-5$ per $\mathrm{mm}$, round; dissepiments thin, entire; pore tubes up to $9 \mathrm{~mm}$ long, light brown; context up to $1.1 \mathrm{~cm}$ thick, usually duplex, 

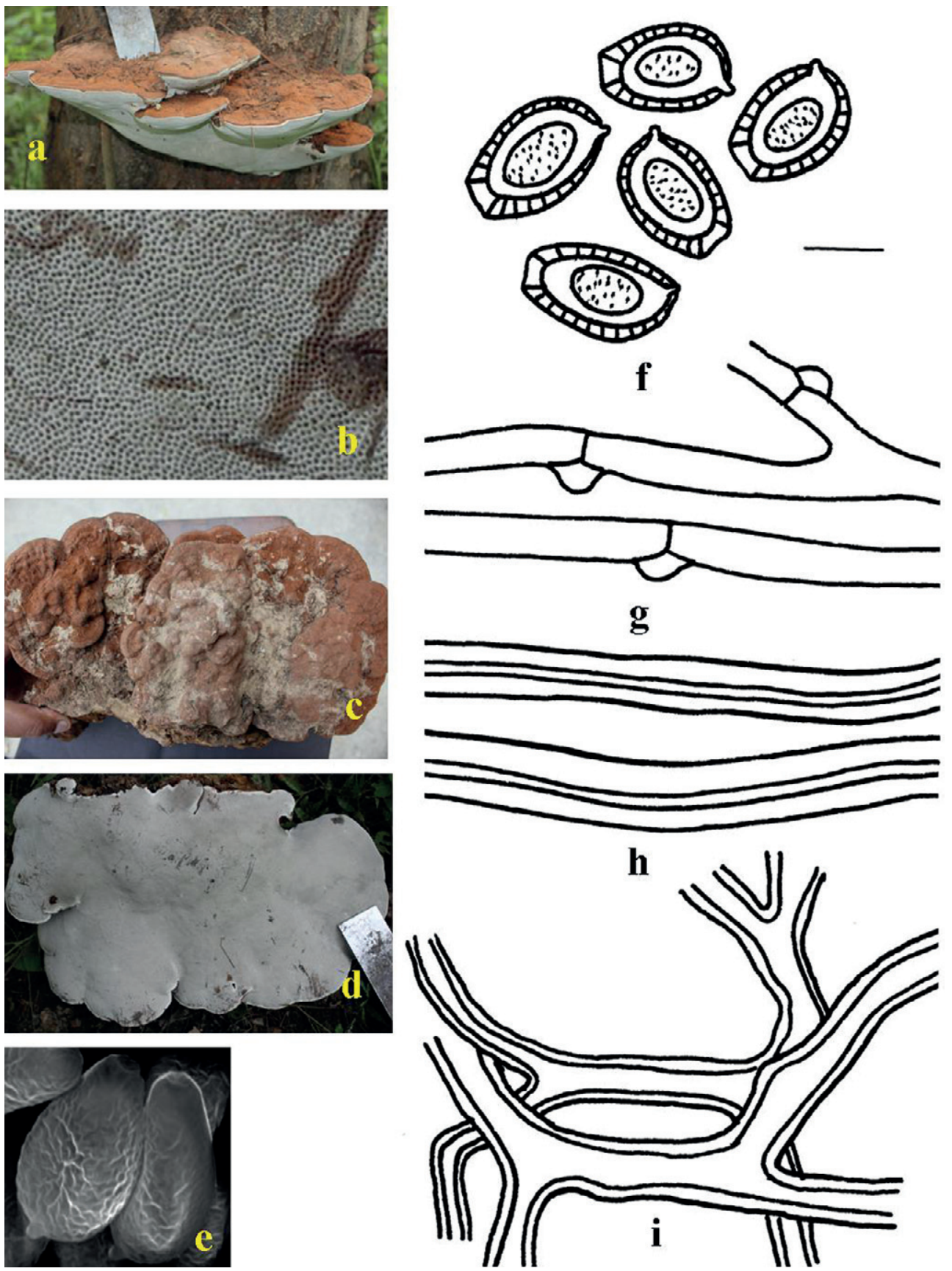

Fig. 6. Ganoderma lobatum: a. Attached sporocarp. b. Hymenial surface showing magnified pores. c, d. Sporocarp showing abhymenial and hymenial surface (dry). e. Basidiospores in SEM. f. Basidiospores. g. Generative hyphae. h. Skeleto-binding hyphae. i. Binding hyphae. Scale bar $(\mathrm{f}-\mathrm{i})=10 \mu \mathrm{m}$ 

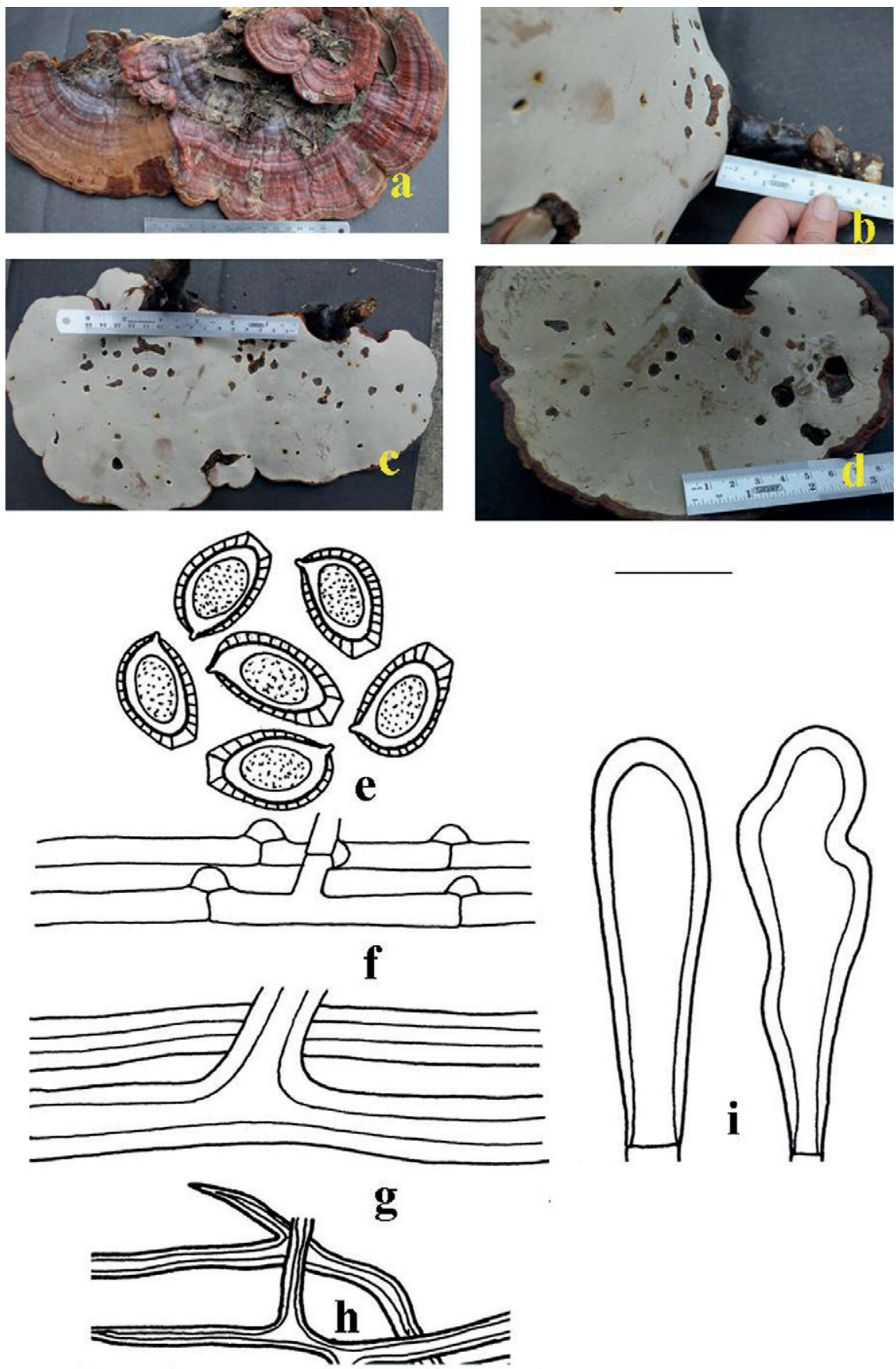

Fig. 7. Ganoderma lucidum: a. Sporocarp showing abhymenial surface. b. Sporocarp showing stipe and hymenial surface. $c$, d. Sporocarp showing hymenial surface (c - fresh, d dry). e. Basidiospores. f. Generative hyphae. g. Skeleto-binding hyphae. h. Binding hyphae. i. Cuticular elements. Scale bar $(\mathrm{e}-\mathrm{i})=10 \mu \mathrm{m}$ 
light brown towards the abhymenial side, reddish brown towards pore tubes, ocassionally homogeneous; margins obtuse, irregularly wavy to lobed, involute, concolorous on the abhymenial side, sterile up to $5 \mathrm{~mm}$, reddish brown on the hymenial side. Stipe up to $9 \times 3.5 \mathrm{~cm}$, eccentric, subcylindrical, solid, violet brown, laccate. Pilear crust as hymeniodermis. Cuticular elements 33-37 × 8.7-11 $\mu \mathrm{m}$, clavate, smooth, thick-walled, inamyloid. Hyphal system trimitic. Generative hyphae up to $2.8 \mu \mathrm{m}$ wide, branched, septate, clamped, thin-walled. Skeleto-binding hyphae up to $5.9 \mu \mathrm{m}$ wide, occasionally with arboriform branching, non-septate, thick-walled. Binding hyphae up to $2.5 \mu \mathrm{m}$ wide, sinuous, branched (bovista type), non-septate, thick-walled. Basidia not seen. Basidiospores 9-11.3 × 5.9-6.6 $\mathrm{m}$, ellipsoid to ovoid, truncate at the distal end; guttulate, inamyloid, acyanophilous; perispore thin, subhyaline, smooth; exospore thick, brown; the two walls connected by inter-wall pillars.

Specimens examined: INDIA, Punjab: S.A.S. Nagar, Chattbir zoo, in association with roots of dried angiospermous tree, $30.603^{\circ} \mathrm{N}, 76.792^{\circ} \mathrm{E}$, alt. $275 \mathrm{~m}, 5 \mathrm{Aug} 2015$, Gurpreet and Avneet 8519 (PUN); Jalandhar, Suranussi, associated with roots of dried angiospermous tree, $31.326^{\circ} \mathrm{N}, 75.576^{\circ} \mathrm{E}$, alt. $242 \mathrm{~m}, 5$ Oct 2015, Gurpreet 8520 (PUN).

Comments. This species is characterized by laccate abhymenial surface, eccentric stipe and duplex or homogeneous context. From India, it has earlier been reported/listed from Arunachal Pradesh, Assam, Chandigarh, Himachal Pradesh, Jammu and Kashmir, Kerala, Maharashtra, Manipur, Meghalaya, Mizoram, Nagaland, Punjab, Tripura, West Bengal and Uttarakhand (Bose 1920, 1922, 1937; Banerjee 1947; Thind et al. 1957; Bakshi 1971; Dhanda 1977; Sharma 1985, 2000, 2012; Singh 1987; Sharma \& Ghosh 1989; Dulat 1992; Leelavathy \& Ganesh 2000; Lalji 2003; Dargan et al. 2006; Bhosle et al. 2010; Kaur 2013; Ranadive et. al. 2011; Ranadive 2013; Singh 2016).

8. Ganoderma mediosinense J.D. Zhao, Acta Mycologica Sinica 7(4): 205, 1988 . Fig. 8 Sporocarps annual, rosette-like, stipitate, pileus up to $12 \times 13 \times 2.2 \mathrm{~cm}$, reniform, corky; abhymenial surface laccate, sulcate, zonate, garnet brown to reddish brown when fresh as well as on drying; hymenial surface poroid, reddish grey when fresh, greyish brown to brown on bruising, not changing much on drying; pores 4-5 per $\mathrm{mm}$, round to angular; dissepiments thin, entire; pore tubes up to $6 \mathrm{~mm}$ long, light brown; context up to $1.6 \mathrm{~cm}$ thick, fibrous, homogeneous, reddish brown; margins acute to somewhat obtuse, regular to irregularly wavy, pale orange to greyish orange on abhymenial side, brown on the hymenial side, sterile up to $4 \mathrm{~mm}$. Stipe up to $10 \times 3 \mathrm{~cm}$, eccentric, complanate, solid, violet-brown, laccate; stipes of adjoining sporocarps fused. Pilear crust as hymeniodermis. Cuticular elements $26-44 \times 7.5-10.3 \mu \mathrm{m}$, subclavate, smooth, thickwalled, brown, inamyloid. Hyphal system trimitic. Generative hyphae up to $2.8 \mu \mathrm{m}$ wide, branched, septate, clamped, thin-walled, subhyaline. Skeleto-binding hyphae up to $5.6 \mu \mathrm{m}$ wide, non-septate, thick-walled, occasionally branched. Binding hyphae up to $3.6 \mu \mathrm{m}$ wide, much branched, non-septate, thick-walled. Basidia not seen. Basidiospores 9-10.5 × 5.6-6.7 $\mu \mathrm{m}$, ellipsoid to ovoid, truncate at the distal end; guttulate, inamyloid, acyanophilous; perispore thin, subhyaline, smooth; exospore thick, brown; the two walls connected by inter-wall pillars. 

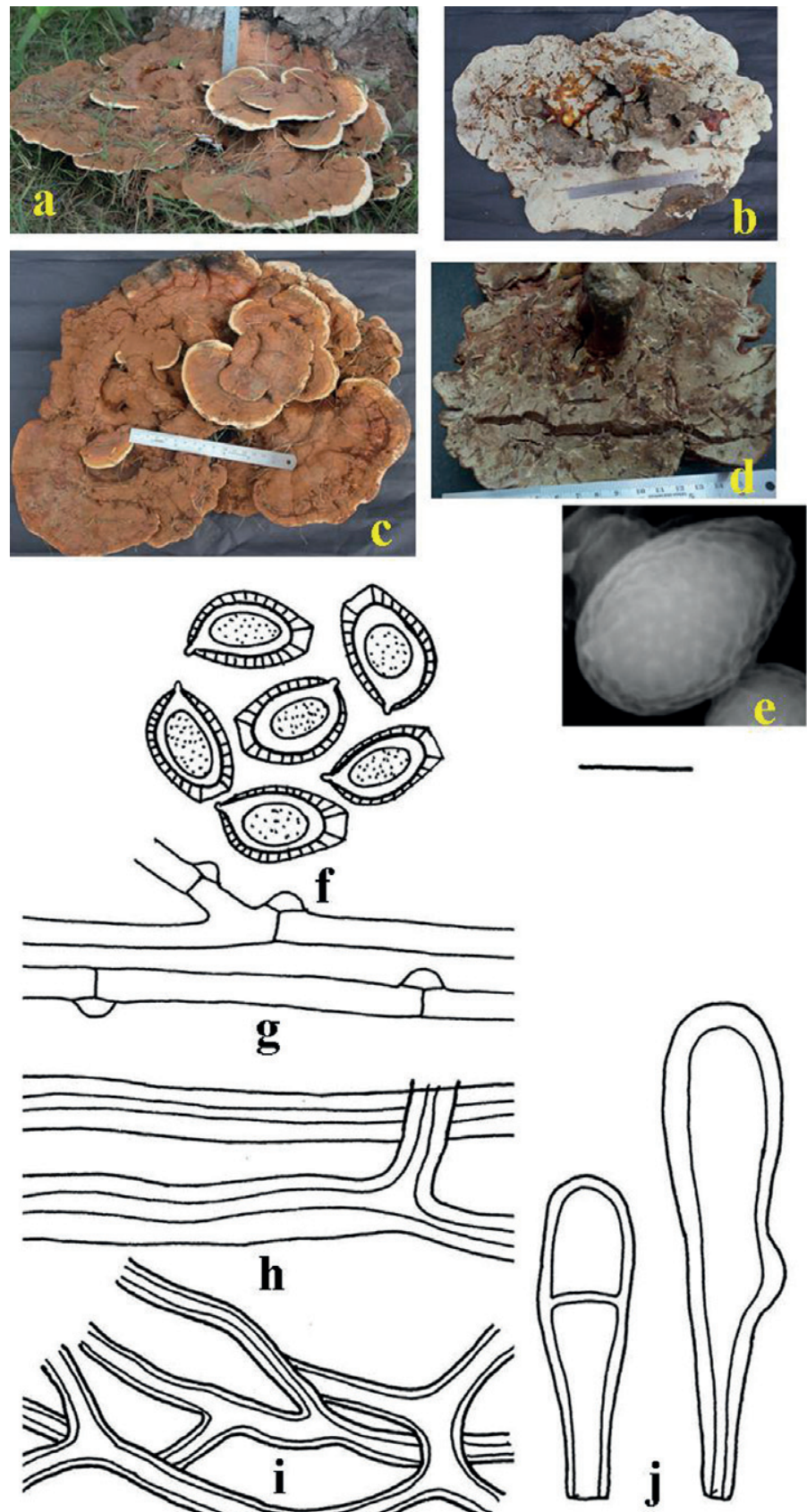

Fig. 8. Ganoderma mediosinense: a. Attached sporocarp showing abhymenial surface. b. Sporocarp showing hymenial surface (fresh). c, d. Sporocarp showing abhymenial and hymenial surface (dry). e. Basidiospore in SEM. f. Basidiospores. g. Generative hyphae. h. Skeleto-binding hyphae. i. Binding hyphae. j. Cuticular elements. Scale bar $(f-j)=10 \mu \mathrm{m}$ 
Specimens examined: INDIA, Union Territory of Chandigarh: Sector 18 D park, in association with roots of Cassia fistula, $30.741^{\circ} \mathrm{N}, 76.768^{\circ} \mathrm{E}$, alt. $341 \mathrm{~m}, 1$ Sept 2015, Dhingra 8521 (PUN); Punjab: Patiala, Punjabi University, opposite Botanic Gardens, in association with roots of C. siamea, $30.320^{\circ} \mathrm{N}, 76.400^{\circ} \mathrm{E}$, alt. $256 \mathrm{~m}, 5$ Aug 2015, Gurpreet and Navpreet, 8522 (PUN).

Comments. Ganoderma mediosinense is distinguished from other species of Ganoderma in having rosette-like sporocarps with eccentric and fused stipes in combination with ellipsoid to ovoid basidiospores. This species is reported herein for the first time from India. It has been previously recorded only from China (Ding 1989).

9. Ganoderma parvulum Murrill, Bulletin of the Torrey Botanical Club 29: 605, 1902.

Fig. 9

Sporocarp annual, sessile, pilei up to $14 \times 11 \times 2 \mathrm{~cm}$, applanate, corky; abhymenial surface laccate, sulcate, irregularly zonate, reddish brown to violet-brown when fresh, not changing much on drying; hymenial surface poroid, brownish orange when fresh, not changing much on drying; pores 4-5 per mm, semicircular; dissepiments thin, entire; pore tubes up to $1.2 \mathrm{~cm}$ long, brown; context up to $8 \mathrm{~mm}$ thick, duplex, reddish brown near the pore tubes, light brown towards the abhymenial side; margins acute to obtuse, irregularly wavy to somewhat lobed, concolorous on the abhymenial side, reddish-greyish red, sterile up to $4 \mathrm{~mm}$ on the hymenial side. Pilear crust as hymeniodermis. Cuticular elements 34$74.5 \times 9-12.8 \mu \mathrm{m}$, clavate to subclavate, sinuous, rarely lobed, thick-walled, encrusted with granular matter at the apex, weakly amyloid. Hyphal system trimitic. Generative hyphae up to $2.2 \mu \mathrm{m}$ wide, branched, septate, clamped, thin-walled. Skeleto-binding hyphae up to 7 $\mu \mathrm{m}$ wide, rarely with arboriform branching, non-septate, thick-walled. Binding hyphae up to $3.7 \mu \mathrm{m}$ wide, much branched, non-septate, thick-walled. Basidia not seen. Basidiospores 7.4-10.5 × 4.9-6.8 $\mu \mathrm{m}$, ellipsoid to ovoid, truncate at the distal end; guttulate, inamyloid, acyanophilous; perispore thin, subhyaline, smooth; exospore thick, brown, the two walls connected by inter-wall pillars.

Specimen examined: INDIA, Punjab: Patiala, Urban Estate Phase II, in association with roots of dried angiospermous tree, $30.487^{\circ} \mathrm{N}, 76.817^{\circ} \mathrm{E}$, alt. $256 \mathrm{~m}, 13$ Aug 2013, Gurpreet and Avneet 8523 (PUN).

Comments. This laccate species is peculiar in having weakly amyloid, clavate to subclavate, sinuous, rarely lobed, thick-walled cuticular elements encrusted with granular matter at the apex. It is reported herein for the first time from Punjab. Earlier from India, it has been reported/listed from Maharashtra (Bhosle et al. 2010; Ranadive et al. 2011; Ranadive 2013) and Uttarakhand (Singh 2016).

10. Ganoderma ramosissimum J.D. Zhao, Acta Mycologica Sinica 8(1): 29, 1989. Fig. 10 Sporocarps annual, stipitate, pilei up to $15 \times 10 \times 2 \mathrm{~cm}$, semicircular to dimidiate to reniform to irregular; abhymenial surface laccate, smooth to radially-sulcate to somewhat zonate specially near the margins, brownish-orange to reddish brown to violet-brown when fresh, not changing much on drying; hymenial surface poroid, orange-white to reddish to greyish brown when fresh, not changing much on drying; pores 5-7 per 

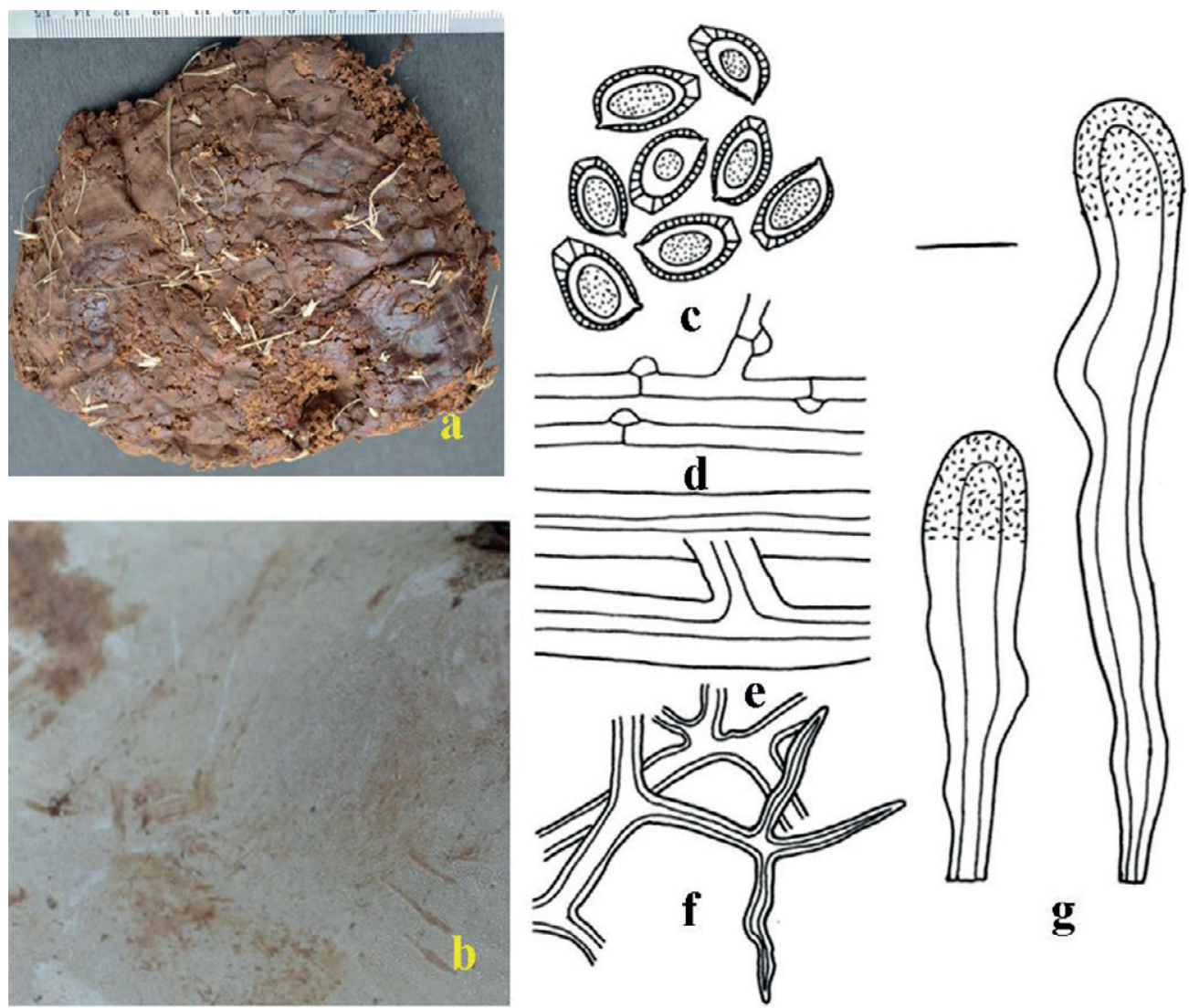

Fig. 9. Ganoderma parvulum: a, b. Sporocarp showing abhymenial and hymenial surface. c. Basidiospores. d. Generative hyphae. e. Skeleto-binding hyphae. f. Binding hyphae. g. Cuticular elements. Scale bar $(\mathrm{c}-\mathrm{g})=10 \mu \mathrm{m}$

$\mathrm{mm}$, round; dissepiments thick, entire; pore tubes up to $8 \mathrm{~mm}$ long, greyish brown to light brown; context up to $1.2 \mathrm{~cm}$ thick, light brown to dark brown; margins irregular, wavy to lobed, acute to obtuse, reddish white on the abhymenial side, sterile up to 4 $\mathrm{mm}$, brownish orange on the hymenial side. Stipe dichotomously to trichotomously to irregularly branched, up to $13 \times 5 \mathrm{~cm}$, eccentric to lateral, subcylindrical, solid, somewhat complanate, violet-brown, strongly laccate. Pilear crust as hymeniodermis. Cuticular elements $26-67 \times 6.2-10 \mu \mathrm{m}$, clavate to subclavate to subcylindrical, rarely lobed, smooth, thick-walled, dextrinoid. Hyphal system trimitic. Generative hyphae up to $2.8 \mu \mathrm{m}$ wide, branched, septate, clamped, thin-walled. Skeleto-binding hyphae up to $5.7 \mu \mathrm{m}$ wide, rarely with arboriform branching, non-septate, thick-walled. Binding hyphae up to $3.1 \mu \mathrm{m}$ wide, much branched, non-septate, thick-walled, sinuous. Basidia not seen. Basidiospores 8-11.3 × 5.3-6.9 $\mu \mathrm{m}$, ellipsoid to ovoid, truncate at the distal 

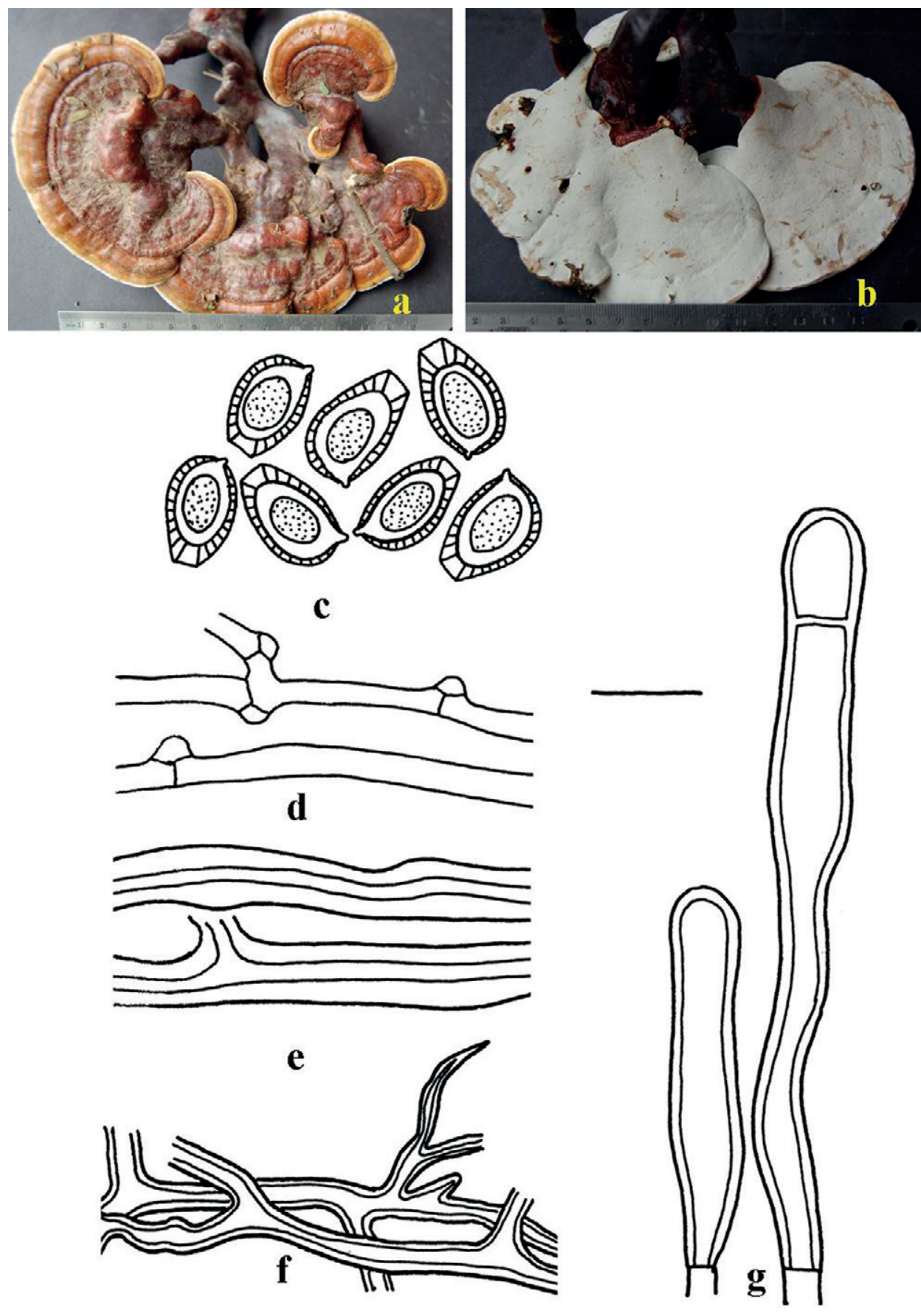

Fig. 10. Ganoderma ramosissimum: a, b. Sporocarp showing abhymenial and hymenial surface. c. Basidiospores. d. Generative hyphae. e. Skeleto-binding hyphae. f. Binding hyphae. g. Cuticular elements. Scale bar $(\mathrm{c}-\mathrm{g})=10 \mu \mathrm{m}$ 
end; guttulate, inamyloid, acyanophilous; perispore thin, subhyaline, smooth; exospore thick, brown bearing an inter-wall pillars.

Specimens examined: INDIA, Union Territory of Chandigarh: Industrial area, in association with roots of Mangifera indica, $30.708^{\circ} \mathrm{N}, 76.805^{\circ} \mathrm{E}$, alt. $338 \mathrm{~m}, 15 \mathrm{Aug} 2013$, Dhingra 8524 (PUN); Sector-21, in association with roots of dried angiospermous tree, $30.725^{\circ} \mathrm{N}, 76.781^{\circ} \mathrm{E}$, alt. $340 \mathrm{~m}, 15$ Aug 2015, Gurpreet and Dhingra 8525 (PUN); Sarover Path, Sector 20, in association with roots of Ficus infectoria, $30.722^{\circ} \mathrm{N}, 76.776^{\circ}$ E, alt. 342 m, 15 Aug 2013, Gurpreet and Dhingra 8526 (PUN); Punjab: Amritsar, Near Wagah border, in association with roots of Pyrus sp., $31.604^{\circ} \mathrm{N}, 74.574^{\circ} \mathrm{E}$, alt. $230 \mathrm{~m}, 1$ Sept 2015, Gurpreet 8527 (PUN); Amritsar, Majitha road bye pass, in association with roots of $M$. indica, $31.669^{\circ}$ N. $74.894^{\circ}$ E, alt. 232 m, 2 Sept 2015, Gurpreet 8528 (PUN); Amritsar, Near Wagah border, in association with roots of Pyrus sp., $31.604^{\circ} \mathrm{N}, 74.574^{\circ} \mathrm{E}$, alt. 230 m, 1 Sept 2015, Gurpreet 8529 (PUN); Guru Nanak Dev University, behind the library, in association with roots of Delonix regia, $31.633^{\circ} \mathrm{N}, 74.825^{\circ} \mathrm{E}$, alt. $230 \mathrm{~m}, 1 \mathrm{Sept}$ 2015, Gurpreet 8530 (PUN).

Comments. This species is peculiar in having dichotomous to trichotomous to irregularly branched stipe. It is reported herein for the first time from the study area. From India, it has earlier been described from Himachal Pradesh (Kaur 2013) and Uttarakhand (Singh 2016).

11. Ganoderma resinaceum Boud., Bulletin de la Société Mycologique de France 5: 72, 1889.

Fig. 11

Sporocarps annual, substipitate to stipitate, pileus up to $15 \times 10 \times 1.2 \mathrm{~cm}$, imbricate, semicircular to dimidiate, laterally fused, corky; abhymenial surface laccate, sulcate, somewhat zonate, reddish brown to dark brown when fresh, not changing much on drying; hymenial surface poroid, greyish orange when fresh, greyish brown on bruising as well as drying; pores 4-5 per $\mathrm{mm}$, round to angular; dissepiments thin, entire; pore tubes up to 5 $\mathrm{mm}$ long, greyish brown to brown; context up to $7 \mathrm{~mm}$ thick, light brown; margins wavy to irregular, obtuse, concolorous on the abhymenial side and sterile up to $3 \mathrm{~mm}$, reddish brown on the hymenial side. Stipe up to $5.5 \times 8.5 \mathrm{~cm}$, torulose, solid, violet brown, laccate, fused laterally. Pilear crust as hymeniodermis. Cuticular elements $24-48 \times 8.7-16.5 \mu \mathrm{m}$, clavate, usually lobed, smooth, thick-walled, weakly amyloid. Hyphal system trimitic. Generative hyphae up to $3.3 \mu \mathrm{m}$ wide, branched, septate, clamped, thin-walled. Skeletobinding hyphae up to $5.3 \mu \mathrm{m}$ wide, rarely with arboriform branching, non-septate, thickwalled. Binding hyphae up to $2.6 \mu \mathrm{m}$ wide, much branched, non-septate, thick-walled, sinuous. Basidia not seen. Basidiospores 8.4-12.5 × 5-6.6 $\mu \mathrm{m}$, ovoid to ellipsoid, truncate at the distal end; guttulate, inamyloid, acyanophilous; perispore thin, subhyaline, smooth; exospore thick, brown, bearing an inter-wall pillars.

Specimens examined: INDIA, Union Territory of Chandigarh: Sector $18 \mathrm{C}$ park, in association with roots of Melia azederach, $30.730^{\circ} \mathrm{N}, 76.780^{\circ} \mathrm{E}$, alt. $348 \mathrm{~m}, 18$ Aug 2014, Dhingra 8531 (PUN); Sector $18 \mathrm{C}$ park, in association with roots of M. azedarach, $30.730^{\circ}$ N, $76.780^{\circ}$ E, alt. 348 m, 20 Sept 2015, Dhingra 8532 (PUN); Punjab: Roopnagar, Boat 

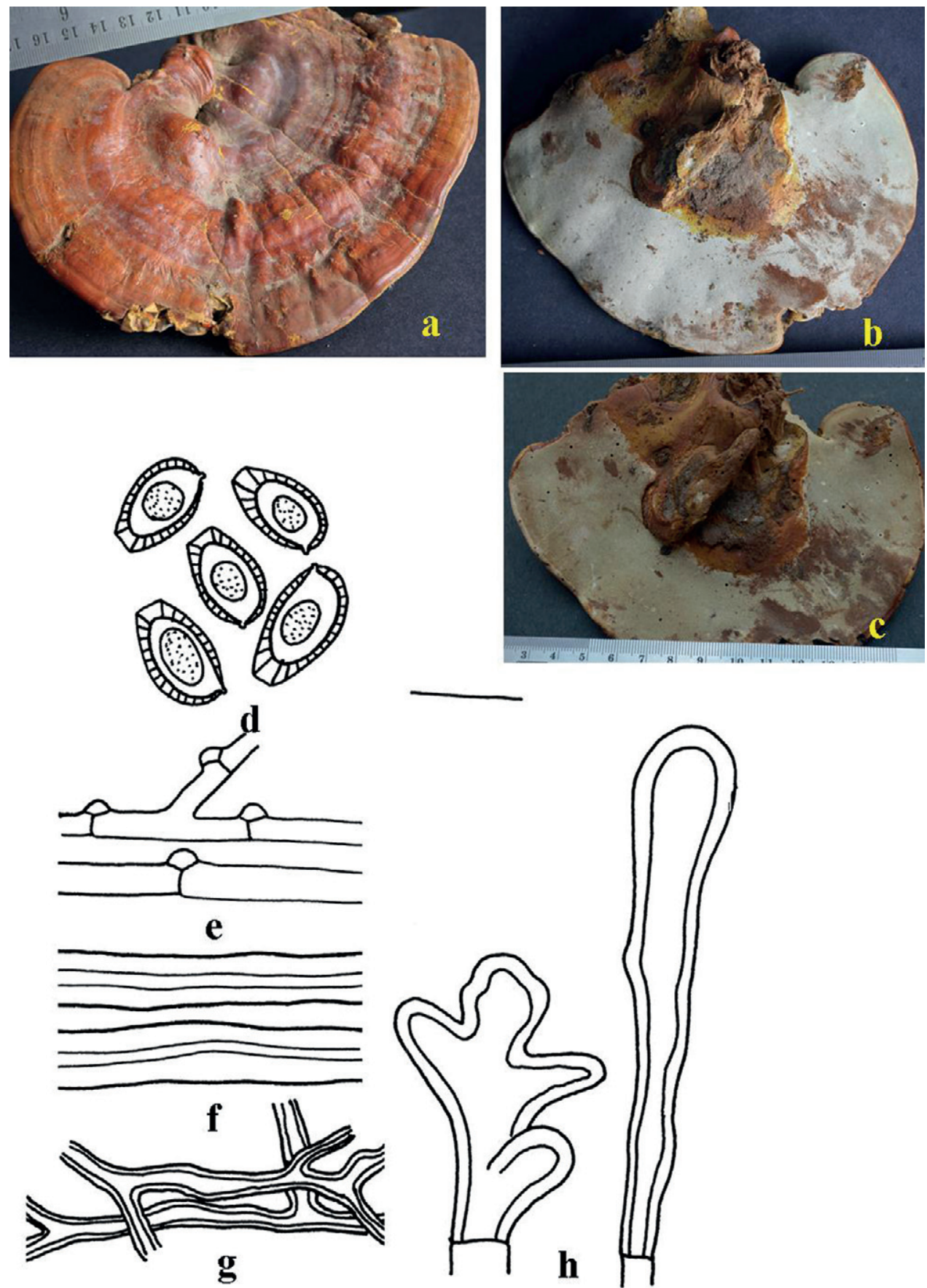

Fig. 11. Ganoderma resinaceum: a. Sporocarp showing abhymenial surface (fresh). b, c. Sporocarp showing hymenial surface (b-fresh, $c-d r y)$. d. Basidiospores. e. Generative hyphae. f. Skeleto-binding hyphae. g. Binding hyphae. h. Cuticular elements. Scale bar (dh) $=10 \mu \mathrm{m}$ 

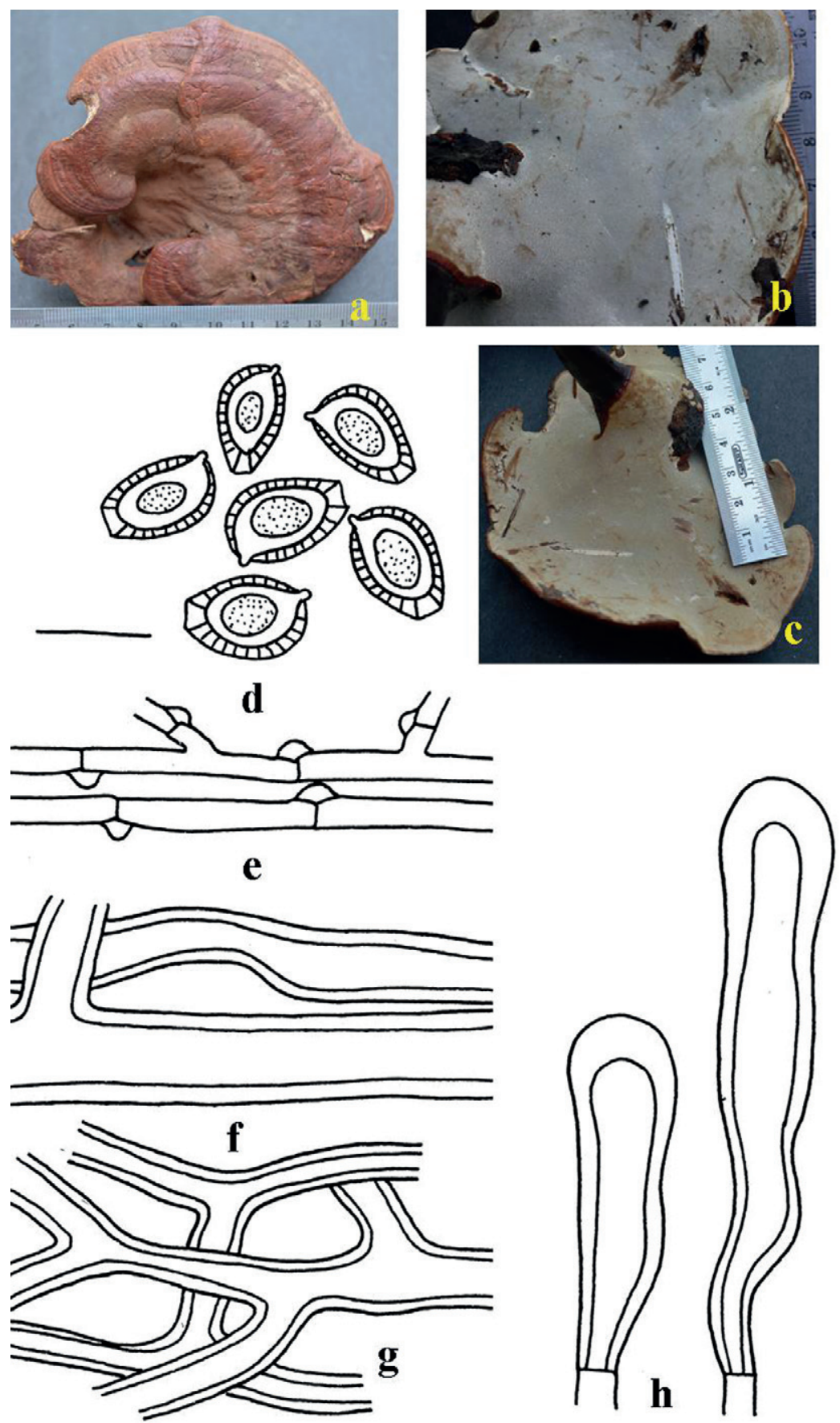

Fig. 12. Ganoderma subumbraculum: a. Sporocarp showing abhymenial surface (fresh). b, c. Sporocarp showing hymenial surface (b - fresh, c - dry). d. Basidiospores. e. Generative hyphae. f. Skeleto-binding hyphae. g. Binding hyphae. h. Cuticular elements. Scale bar (dh) $=10 \mu \mathrm{m}$ 
Club, in association with roots of dried angiospermous tree, $30.965^{\circ} \mathrm{N}, 76.523^{\circ} \mathrm{E}$, alt. 262 m, 5 Sept 2012, Gurpreet and Avneet 8533 (PUN).

Comments. This species is characteristic in having semicircular to dimidiate, imbricate, laterally fused sporocarps. This is a first report from the study area. From India, it has earlier been reported/listed from Himachal Pradesh (Dhanda 1977; Kaur 2013), Jammu \& Kashmir (Dhanda 1977), Maharashtra (Foroutan \& Vaidya 2007; Ranadive et al. 2011; Ranadive 2013), Uttarakhand (Sharma 2000, 2012, Singh 2016), and West Bengal (Sharma 2000, 2012).

12. Ganoderma subumbraculum Imazeki, Bulletin of the Tokyo Science Museum 1: 39, 1939.

Fig. 12

Sporocarp annual, stipitate, pileus up to $11 \times 8 \times 0.8 \mathrm{~cm}$, semicircular, corky; abhymenial surface laccate, sulcate, weakly zonate, brownish red to reddish brown when fresh, not changing much on drying; hymenial surface poroid, reddish grey when fresh, brownish orange to greyish brown on bruising as well as on drying; pores 4-5 per $\mathrm{mm}$, round to angular; dissepiments thick, entire; pore tubes up to $4 \mathrm{~mm}$ long, greyish brown, decurrent; context up to $4 \mathrm{~mm}$ thick, three-layered, light brown zone near the pore tubes, reddish brown in the middle zone and greyish brown zone towards the abhymenial side; margins irregulary wavy to lobed, acute to obtuse, concolorous on abhymenial side, sterile up to $1 \mathrm{~mm}$, reddish white to light brown on the hymenial side. Stipe up to $8 \times 2.3 \mathrm{~cm}$, subcylindrical, complanate in the apical portion, solid, reddish brown to dark brown, laccate. Pilear crust as hymeniodermis. Cuticular elements $28-54 \times 8.2-10.5 \mu \mathrm{m}$, subclavate to clavate, smooth, thick-walled, yellowish brown, inamyloid. Hyphal system trimitic. Generative hyphae up to $3 \mu \mathrm{m}$ wide, branched, septate, clamped, thin-walled, subhyaline. Skeleto-binding hyphae up to $9 \mu \mathrm{m}$ wide, rarely with arboriform branching, non-septate, thick-walled, yellowish brown. Binding hyphae up to $4.5 \mu \mathrm{m}$ wide, much branched, non-septate, thick-walled. Basidia not seen. Basidiospores 7.6-11.2 × 4.7-7.5 $\mu \mathrm{m}$, broadly ellipsoid to ovoid, truncate at the distal end; guttulate, inamyloid, acyanophilous; perispore thin, subhyaline, smooth; exospore thick, brown, the two walls connected by inter-wall pillars.

Specimen examined: INDIA, Punjab: Roopnagar, Boat Club, in association with roots of dried angiospermous tree, $30.965^{\circ} \mathrm{N}, 76.523^{\circ} \mathrm{E}$, alt. $262 \mathrm{~m}, 5$ Sept 2012, Gurpreet and Avneet 8534 (PUN).

Comments. Ganoderma subumbraculum differs from all other species within the genus in having three zoned context. It is reported herein for the first time from Punjab. From India, it has earlier been reported from Uttarakhand (Singh 2016).

Acknowledgments. The authors thank SERB, Department of Science and Technology, Government of India, New Delhi, India for financial assistance and Head, Department of Botany, Punjabi University, Patiala for providing research facilities.

Author contributions. All the authors, namely Ms. Gurpreet Kaur, Dr. Avneet Pal Singh, and Dr. Gurpaul Singh Dhingra, conducted the fungal forays in different localities of the 
study area and collected the specimens of the genus Ganoderma. Ms. Gurpreet Kaur worked out the macro and micromorphological details of the collected specimens and prepared the line drawings. Dr. Avneet Pal Singh and Dr. Gurpaul Singh Dhingra analyzed the macro and micromorphological data and confirmed the identification of the specimens.

Conflict of interest. The authors declare no conflict of interest.

\section{References}

Bagchee, K.D., Puri, Y.N. \& Bakshi, B.K. 1954. Principal diseases and decays of Oaks and other hard woods in India II. - Indian Phytopathology 7: 18-42.

Bakshi, B.K. 1971. Indian Polyporaceae (on trees and timber). Indian Council of Agricultural Research, New Delhi, India.

Banerjee, S.N. 1947. Fungus flora of Calcutta and Suburbs I. - Bulletin of the Botanical Society of Bengal 1: 37-54.

Bhosle, S.R., Ranadive, K., Bapat, G., Garad, S., Deshpande, G. \& Vaidya, J. 2010. Taxonomy and diversity of Ganoderma from the Western parts of Maharashtra (India). - Mycosphere 1: 249-262.

Bose, S.R. 1920. Fungi of Bengal: Polyporaceae of Bengal-III. - Bulletin of Carmichael Medical College 1: $1-5$.

Bose, S.R. 1922. Polyporaceae of Bengal-V. - Bulletin of Carmichael Medical College 3: 20-25.

Bose, S.R. 1937. Polyporaceae of Lokra Hills, Assam. - Annales Mycologici 35: 119-137.

Champion, H.G. \& Seth, S.K. 1968. A revised survey of the forest types of India. Government of India Publication, New Delhi.

Corner, E.G.H. 1983. Ad Polyporaceas-I. Amauroderma and Ganoderma. - Beihefte zur Nova Hedwigia 75: 1-182.

Dargan, J.S., Lalji, K. \& Singh, A.P. 2006. Mycoflora associated with Bauhinia purpurea Linn. - Bionature 26(1): 33-38.

Dhanda, R.S. 1977. Studies on Polyporaceae of North Western Himalaya. PhD thesis. Panjab University, Chandigarh, India.

Ding, Z.H. 1989. The Ganodermataceae in China. - Bibliotheca Mycologica 132: 1-175.

Dulat, A.K. 1992. Mycoflora associated with pathological problems of some multipurpose tree species of Punjab. M. Phil. thesis. Punjabi University, Patiala, India.

Foroutan, A. \& Vaidya, J.G. 2007. Records of new species of Ganoderma in Maharashtra India. - Asian Journal of Plant Sciences 6: 913-919. https://doi.org/10.3923/ajps.2007.913.919

Karsten, P.A. 1881. Symbolae ad mycologiam fennicam. VII. - Meddelanden af Societas pro Fauna et Flora Fennica 6: 1-6.

Kaur, H. 2013. Systematics of pileate poroid Agaricomycetes of Himachal Pradesh. PhD thesis. Punjabi University, Patiala, India.

Lalji, K. 2003. Mycoflora associated with multipurpose tree species of North-West India. PhD thesis. Punjabi University, Patiala, India.

Leelavathy, K.M. \& Ganesh, P.N. 2000. Polypores of Kerala. Daya Publishing House, New Delhi, India. Moncalvo, J.M. \& Ryvarden, L. 1997. A nomenclatural study of Ganodermataceae Donk. - Synopsis Fungorum 11: 1-114. 
Murrill, W.A. 1902. The Polyporaceae of North America. I. The genus Ganoderma. - Bulletin of the Torrey Botanical Club 29: 599-608. https://doi.org/10.2307/2478682

Mycobank. 2017. Fungal databases. Nomenclature and species banks. Available from http://www.mycobank. org (accessed 27 November 2017).

Núňez, M. \& Ryvarden, L. 2000. East Asian Polypores, vol. 1 - Ganodermataceae and Hymenochaetaceae.Synopsis Fungorum 13: 1-200.

Ranadive, K.R. 2013. An overview of Aphyllophorales (wood rotting fungi) from India. - International Journal of Current Microbiology and Applied Sciences 2(12): 112-139.

Ranadive, K.R., Vaidya, J.G., Jite, P.K., Ranade, V.D., Bhosle, S.R., Rabba, A.S., Hakimi, M., Deshpande, G.S., Rathod, M.M., Forutan, A., Kaur, M., Naik-Vaidya, C.D., Bapat, G.S. \& Lamrood, P. 2011. Checklist of Aphyllophorales from the Western Ghats of Maharashtra State, India. - Mycosphere 2: 91-114.

Ryvarden, L. \& Gilbertson, R.L. 1993. European polypores. Vol. 1. Pp. 1-387. Fungiflora, Oslo, Norway. Ryvarden, L. \& Melo, I. 2014. Poroid fungi of Europe. - Synopsis Fungorum 31: 1-455.

Saxena, M.C. 1961. Fleshy fungi of Raipur District (Madhya Pradesh) Polyporaceae-III. -In: Proceedings of the $48^{\text {th }}$ Indian Science Congress Association, Part III: 245-246.

Sharma, J.R. 1985. Studies on Polyporaceae of Himachal Pradesh. - Journal of Economic and Taxonomic Botany 7: 95-101.

Sharma, J.R. 2000. Genera of Indian polypores. Botanical Survey of India, Calcutta.

Sharma, J.R. 2012. Aphyllophorales of Himalaya. Botanical Survey of India, Calcutta.

Sharma, J.R. \& Ghosh, P.K. 1989. Polypores that decay tree of Indian Botanic Garden. - Bulletin of Botanical Survey of India 31: 95-102.

Singh, R. 2016. Taxonomic studies, biochemical analysis and evaluation of CNS activities of some species of Ganoderma from Uttarakhand. PhD thesis. Punjabi University, Patiala, India.

Singh, S. 1987. Studies on polyporoid fungi of Eastern Himalaya and adjoining areas. PhD thesis. Panjab University, Chandigarh, India.

Steyaert, R.L. 1972. Species of Ganoderma and related genera mainly of the Bogor and Leiden herbaria. Persoonia 7: 55-118.

Thind, K.S. \& Chatrath, M.S. 1960. The Polyporaceae of the Mussoorie hills-I. - Indian Phytopathology 13: 76-89.

Thind, K.S., Bindra, P.S. \& Chatrath, M.S. 1957. The Polyporaceae of the Mussoorie hills-III. - Research Bulletin (N.S.) Panjab University Chandigarh 129: 471-483. 